\title{
EMOCJE ODZYSKANE W TŁUMACZENIU: O AUDIODESKRYPCJI ARTYSTYCZNEJ I PRZEKŁADZIE HUMORU
}

\section{Abstract \\ Emotions Recovered in Translation: On Artistic Audio Description and Translation of Humour}

The subject of this paper is audio description (AD) or, more precisely, artistic $\mathrm{AD}$, by which I understand any AD whose language and form are adjusted to the product it is accompanying and which not only informs about the content of the visual layer of the movie, but is also able to recreate its unique character. The article presents the results of a comparative analysis of some scenes of the film The Intouchables and a Polish AD prepared for that film. The aim of the study was to establish how much of the original character of the film (especially the emotions and humour included in its scenes) the authors of the $\mathrm{AD}$ were able to preserve, how much was lost, and why. Although the $\mathrm{AD}$ for The Intouchables is written in a rich and colourful language, it can be classified as traditional. This, in turn, may be a starting point to consider whether giving it a more artistic form has the potential to contribute to a better rendition of the filmic humour. The conclusions of the study are part of wider reflection concerning the ability of AD to influence the mood of the audience. This is why the text is additionally illustrated with a number of examples from Polish and foreign ADs (which can be perceived as artistic) prepared for various movies of different genres.

Keywords: audio description (AD), artistic audio description, translating emotions, translation of humour

Słowa kluczowe: audiodeskrypcja (AD), audiodeskrypcja artystyczna, emocje w przekładzie, komizm w przekładzie 


\section{Wprowadzenie: audiodeskrypcja, czyli obraz w przekładzie}

Audiodeskrypcja (dalej: AD) to wyjątkowy rodzaj przekładu audiowizualnego polegający na przedstawieniu obrazów za pomocą słów, a jej podstawowym celem jest możliwie najpełniejsze udostępnianie informacji wizualnych osobom z dysfunkcją wzroku. Jest to możliwe poprzez dołączenie do różnych wytworów sztuk wizualnych (np. do filmu, przedstawienia teatralnego, rzeźby czy obrazu) oraz wydarzeń sportowych i kulturalnych dodatkowej ścieżki dźwiękowej dostarczającej niewidomym odbiorcom tych informacji, które przez osoby widzące są odbierane za pomocą zmysłu wzroku (m.in. Braun 2007; Chmiel, Mazur 2011; Branje, Fels 2012). Innymi słowy, odbiorca słyszy opis - a niekiedy również interpretację - tego, co jest przedstawione w warstwie wizualnej danego dzieła.

$\mathrm{W}$ miarę rozwoju AD (zarówno na gruncie naukowym, jak i w bardziej praktycznym wymiarze) coraz częściej podnoszą się głosy za tym, że należałoby przestać patrzeć na AD wyłącznie jako na źródło informacji, a bardziej docenić jej artystyczny aspekt, to jest funkcję estetyczną oraz możliwości, jakie stwarza w zakresie rozrywki oferowanej odbiorcom. W ten sposób podejmowany jest temat AD artystycznej, czyli AD dopasowanej swoim językiem i formą do dzieła, któremu towarzyszy - takiej, która informując o zawartości treściowej warstwy wizualnej, możliwie najwierniej oddaje kreowany przez tę warstwę nastrój. Zagadnienie to nie było do tej pory omawiane na szerszą skalę w literaturze przedmiotu, jakkolwiek w dyskursie nad rozwojem AD pojawiał się już temat między innymi AD pisanej w metrum dostosowanym do metrum audiodeskrybowanej sztuki (Udo, Fels 2011), AD pierwszoosobowej (Fels et al. 2006; Orero 2011; Benecke $2015^{1}$ ) czy rymowanej (Zabrocka 2014a, 2014b). O nietypowej AD pisali także Agnieszka Szarkowska² i Piotr Wasylczyk w artykule zatytułowanym Audiodeskrypcja autorska (2014) oraz Robert Więckowski w artykule Audiodeskrypcja piękna (2014).

${ }^{1}$ AD pierwszoosobową przygotowaną do pełnometrażowego filmu dla dzieci i młodzieży Benecke nazywa „AD eksperymentalną”.

${ }^{2} \mathrm{O}$ badaniach na temat nietypowych form AD Szarkowska wspomina również, choć na marginesie, w artykule zatytułowanym Text-to-Speech Audio Description: Towards Wider Availability of $A D$ (2011). 


\section{Audiodeskrypcja artystyczna w teorii}

Dzieło filmowe bez wątpienia można uznać za tekst, wypowiedź, a zatem komunikat, któremu wyznaczono określoną funkcję, zazwyczaj więcej niż jedną: ma za zadanie na przykład informować lub uczyć widza, dostarczać mu rozrywki, śmieszyć go, wzruszać czy trzymać w napięciu. Film - jak każdy inny tekst kultury - może spełnić zakładane funkcje tylko wtedy, gdy jego autor zastosuje odpowiednie środki ekspresji. Ponieważ jest też dziełem sztuki, ma każdorazowo do spełnienia również funkcję estetyczną, która w przypadku niektórych produkcji może być nawet uznana za nadrzędną w stosunku do pozostałych, jeśli reżyser szczególną wagę przyłożył do kompozycji scen czy techniki montażu. Tak jak warstwa wizualna filmu, zastępująca ją ścieżka AD razem z oryginalną ścieżką dźwiękową tworzy spójną całość i powinna spełniać te same funkcje co obraz. Podstawowym narzędziem AD jest język, któremu Jakobson w swojej często przywoływanej kategoryzacji przypisuje sześć funkcji: poznawczą (powszechnie uznawaną za najważniejszą w większości komunikatów), emotywną, konatywną, fatyczną, metajęzykową i estetyczną (tj. poetycką). Jakobson dowodzi też, że nie ma komunikatu, który spełniałby tylko jedną funkcję, zaś sama jego struktura zależy od tego, która z funkcji jest funkcją główną (Jakobson 1960 , por. Waugh 1980).

Uwzględniając powyższe uwagi, można stwierdzić, że autor AD tworzonej do jakiegokolwiek dzieła sztuki (w wypadku tego artykułu jest to dzieło filmowe) musi mieć na uwadze kilka kwestii. Po pierwsze to, aby $\mathrm{AD}$ pełniła funkcję informacyjną wynikającą $\mathrm{z}$ jej natury, $\mathrm{w}$ tym aby oprócz podstawowych informacji na temat akcji dostarczała informacji dodatkowych, jak te dotyczące stereotypów zawartych w przedstawianych obrazach czy wywoływanych przez nie skojarzeniach. Ponadto AD ma pełnić inne funkcje - te, które pełni zastępowana przez nią warstwa wizualna dzieła sztuki, a zatem na przykład uczyć, bawić, śmieszyć czy trzymać w napięciu. W końcu, skoro możemy mówić o poetyce obrazu (zazwyczaj w kontekście analizy kompozycji dzieła plastycznego), to konieczne wydaje się wzięcie pod rozwagę także poetyki $\mathrm{AD}$, która zastępuje obraz i przez to niejako automatycznie przejmuje tę (poetycką) rolę. Jest to tym bardziej istotne, że AD to komunikat wyrażony za pomocą elementów językowych, a niezależnie od rodzaju komunikatu nie można mówić o różnych funkcjach języka, zupełnie pomijając jego funkcję estetyczną, skoro kierujemy się nią - świadomie lub 
nie - nawet przy komponowaniu najprostszych, codziennych wypowiedzi (Jakobson 1960, por. Waugh 1980).

Wszystkie wyżej wymienione funkcje AD może pełnić jej styl - adekwatny dla danego gatunku filmowego, a także jej forma. To wyłącznie za ich pośrednictwem można przekazać niewidomemu odbiorcy oryginalny charakter dzieła filmowego oraz przedstawiane w nim i wywoływane przez nie emocje (jakkolwiek nie bez strat, nieuniknionych w procesie przekładu).

\section{Przekład humoru}

Jak zauważa Jeroen Vandaele (2010), zdefiniowanie pojęcia „humor” wydaje się proste: jest to wszystko, co wprawia nas w dobry nastrój, powoduje rozbawienie, spontaniczny uśmiech czy śmiech. Vandaele podkreśla za Terrence'em Deaconem, że humor i towarzyszące mu emocje są związane z najbardziej pierwotnymi częściami mózgu człowieka, odpowiedzialnymi za proces socjalizacji, przeżywanie i współdzielenie emocji oraz poczucie bezpieczeństwa czy zagrożenia. Jednak o ile sam uśmiech czy śmiech są reakcjami wrodzonymi (uśmiech jest przecież jedną z pierwszych form komunikowania się niemowlęcia $\mathrm{z}$ otoczeniem) i nie wymagają wysoce rozwiniętych kompetencji umysłowych, o tyle do zrozumienia żartu, dowcipu, komizmu, aluzji - przeciwnie: konieczne będzie przyswojenie różnych reguł i norm obowiązujących w danej zbiorowości oraz znajomość jej zasobów kulturowych, ponieważ to na ich podstawie i w odniesieniu do nich tworzone jest to, co klasyfikujemy jako humor. Jest on zatem częścią doświadczenia emocjonalnego i gry społecznej, a odpowiedzią na jego obecność są właśnie śmiech, uśmiech czy rozbawienie (Deacon 1997 za Vandaele 2010; Vandaele 1999; Laurian 1989).

Vandaele (2010, 1999) oraz inni autorzy (m.in. Diot 1989; Laurian 1989; Del Corral 1988; Martínez-Sierra 2010; Eco 2003 i Lipiński 2000) piszą, że podobnie jak poezja, humor jest prawdziwym wyzwaniem dla thumacza i podobnie jak ona często bywa uznawany za nieprzekładalny. Debra S. Raphaelson-West (1989) dzieli komizm na trzy kategorie: humor językowy (np. gry słowne), humor o podłożu kulturowym (np. odnoszący się do sposobu postrzegania różnych grup społecznych) oraz humor uniwersalny (np. nieoczekiwane komiczne sytuacje), jednocześnie zaznaczając, że najtrudniejsza czy wręcz niemożliwa nieraz do przełożenia jest kategoria pierwsza, najłatwiejsza zaś ostatnia. Stąd też można pokusić się o stwierdzenie, 
że trudności z przekładem humoru, czy też raczej jego domniemana nieprzekładalność, są ściśle związane z nieprzekładalnością pewnych zjawisk kulturowych, a tłumacz z tymi właśnie czynnikami kulturowymi musi liczyć się na równi z ograniczeniami narzucanymi przez same różnice pomiędzy językiem oryginału i przekładu. Powinien przy tym pamiętać, że aby żart spełnił swoją funkcję, docelowi odbiorcy muszą być zaznajomieni z jego kontekstem kulturowym. Ten stanowi punkt odniesienia, odsłaniając tę nieregularność czy nieoczywistość, która ma śmieszyć. Przygotowując skrypt $\mathrm{AD}$ do komedii, audiodeskryptor ma $\mathrm{w}$ istocie do czynienia z wszystkimi trzema wcześniej wspomnianymi typami komizmu. I choć w przypadku produkcji obcojęzycznych (takim przypadkiem jest omawiany tu film Nietykalni) komizm słowny już wcześniej przełożyła osoba tłumacząca listę dialogową, to jednak w wielu wypadkach właśnie od audiodeskryptora i stworzonego przez niego opisu zależeć będzie, czy dany żart rozbawi niewidomych odbiorców. Na nim spoczywa odpowiedzialność za uzupełnienie żartów słownych o kontekst, o tło, które nada im sens lub choćby „przyda rumieńców”, a co za tym idzie, zapewni pożądaną reakcję widowni. Jak zauważa Juan José Martínez-Sierra (2010), konieczność oddania komizmu warunkowanego przez warstwę wizualną powinna stanowić dla audiodeskryptora priorytet determinujący wybór elementów niezbędnych do ujęcia w skrypcie AD. Głównym wyzwaniem dla autora AD do scen o zabarwieniu humorystycznym jest więc stworzenie opisu klarownego, błyskotliwego, precyzyjnie trafiającego w sedno, stanowiącego zabawny i jednocześnie treściwy przekaz niezbędnych informacji, a czasem też objaśnienie czy nawet komentarz. Jednocześnie musi to być opis zwięzły, co w ogóle stanowi jedno z podstawowych wyzwań, przed jakimi staje autor każdej $\mathrm{AD}$, gdyż w krótkich przerwach pomiędzy dialogami nie ma czasu na długie objaśnienia; te zresztą zabiłyby dowcip.

\section{Przekład emocji}

Temat humoru jest ściśle związany z tematem emocji w ogóle. Emocje oraz powodowane nimi gesty i mimika stanowią nieodłączny element komunikacji językowej i niewerbalnej w interakcjach międzyludzkich. Gesty i mimika, będąc środkami komunikacji niewerbalnej, odgrywają kluczową rolę w ludzkich zachowaniach społecznych, a umiejętność ich interpretacji jest ściśle związana ze znajomością zasad obowiązujących w określonej 
kulturze $^{3}$ i stanowi podstawę efektywnej komunikacji (Argyle 1988; Poyatos 2002; Rossini 2004, 2012). Słowa dialogu nabierają pełnego znaczenia dopiero w kontekście, wliczając w to kontekst towarzyszących im emocji. Nawet jeśli emocje są zazwyczaj słyszalne w głosie mówiącego, przy ich identyfikacji nie należy się sugerować wyłącznie intonacją. Zdecydowanie więcej możemy wyczytać z mimiki, gestów i ruchów ciała, które - nawet jeśli nie wpływają bezpośrednio na narrację - decydują o znaczeniu wypowiadanych słów, a czasami zupełnie je zastępują, stając się jedynym źródłem informacji (Masson 2007; Sweetser 2006). W tekstach polisemiotycznych, do których zaliczają się filmy, gesty towarzyszące wypowiedziom lub je zastępujące (np. gdy nie da się ująć jakichś informacji w ścieżce dialogowej) są kluczowym źródłem danych i w związku z tym nie powinny być pominięte w AD (Jankowska, Zabrocka 2016).

Tak samo ważne jak to, by wiernie opisać emocje przeżywane przez postacie w filmie, jest oddanie nastroju samego dzieła filmowego i emocji, jakie ma wzbudzać w widzach dzięki odpowiedniemu wykorzystaniu różnych filmowych środków wyrazu. W wielu współczesnych scenariuszach kinowych $^{4}$ wciąż z powodzeniem wykorzystuje się schemat znany ze starożytnej tragedii, która, według teorii Arystotelesa, wywoływała w widzach naprzemiennie strach (gr. phobos) i litość (gr. eleos), by umożliwić im przeżycie „oczyszczenia” (gr. katharsis). Takie naprzemienne dawkowanie różnych emocji, od śmiechu, przez współczucie, po gniew czy trwogę - zwłaszcza zaś w kulminacyjnym momencie filmu, kiedy intryga zapętla się, a widz w napięciu oczekuje rozwiązania - nie byłoby możliwe bez umiejętnego wykorzystania przez reżysera elementów języka filmowego. Tak więc na przykład odpowiednia kompozycja sceny, umiejscowienie kamery czy jej ruch, wraz z odpowiednim tłem dźwiękowym, wpływają na to, w jaki sposób widzowie odbierają daną scenę i jakie emocje w nich budzi. By zapewnić osobom widzącym i niewidomym jedność doświadczenia, tak rozumiany język filmu powinien zostać oddany za pomocą języka AD. Ważny więc będzie wybór opisywanych elementów, stopień szczegółowości opisu, kompozycja zdania, dobór słów, a w końcu sposób udźwiękowienia tekstu. Wszystko to z kolei należy dostosować do opisywanego gatunku filmowego, w przeciwnym razie całość nie będzie brzmiała wiarygodnie i zamierzony efekt estetyczny nie zostanie osiągnięty (Künstler 2014).

3 Ten sam gest w różnych kulturach może mieć inne, czasami nawet zupełnie przeciwne znaczenie.

4 To samo tyczy się też np. sztuk teatralnych. 


\section{Język i forma audiodeskrypcji w Nietykalnych}

Jako punkt wyjścia do rozważań w niniejszym artykule posłuży mi analiza opisów zawartych w polskiej audiodeskrypcji ${ }^{5}$ do kinowego hitu - francuskiej produkcji Nietykalni (2011, franc. Intouchables). Ta bazująca na humorze słowno-sytuacyjnym komedia opowiada opartą na prawdziwych wydarzeniach historię sparaliżowanego mężczyzny i jego ekscentrycznego opiekuna. Perypetie obu mężczyzn zarówno bawią, jak i wzruszają widzów, a choć oglądając Nietykalnych, śmiejemy się cały czas, to jednak - co w swojej recenzji zauważa Tadeusz Sobolewski - ten śmiech nie tłumi naszego współczucia $^{6}$. Za pomocą dynamicznie zmieniających się scen, zabawnych sytuacji oraz dowcipnych dialogów reżyser przedstawia każdą z postaci oraz złożoność relacji pomiędzy nimi, jednocześnie klatka po klatce budując obraz przyjaźni zawiązującej się między głównymi bohaterami, którzy z czasem stają się sobie niezwykle bliscy bez względu na różnice dzielące ich niemalże we wszystkich domenach. Zawarte w filmie emocje i nastroje zostały przez reżysera odmalowane w sposób bardzo subtelny, między innymi poprzez mimikę czy gesty postaci, przez co mogą być trudne do oddania za pomocą słów. Dodatkowe utrudnienie stanowi też gatunek filmu, gdyż odtworzenie humoru tekstu wyjściowego jest każdorazowo trudnym zdaniem. W tym wypadku, przy wartkiej akcji filmu, szybkich zmianach scen oraz ograniczeniach czasowych, jakim podlega audiodeskryptor, oddanie komizmu - zwłaszcza przeważającego tu komizmu słowno-sytuacyjnego, z natury wyrażanego zwięźle - wydaje się zadaniem wręcz niemożliwym. Czy i dlaczego emocje z Nietykalnych zostają utracone w thumaczeniu?

Jeśli chodzi o komizm słowny czy słowno-sytuacyjny, to podstawową pracę $\mathrm{w}$ tym zakresie wykonał tłumacz przekładający listę dialogową ${ }^{7}$. Jego zadaniem było zaadaptowanie wypowiedzi postaci do potrzeb i oczekiwań publiczności docelowej, czyli sprawienie, by były zrozumiałe i zabawne w warunkach odbioru tłumaczenia. Tym, co najbardziej śmieszy nas w Nietykalnych, jest typowa dla kina francuskiego gra słów, wypowiedzi delikatnie cyniczne czy ironiczne, których nieodłącznym elementem jest szeroko rozumiana mowa ciała. Znakomita część humoru jest więc efektem

5 Tekst AD: Izabela Künstler i Urszula Butkiewicz.

${ }^{6}$ Por.http://m.wyborcza.pl/wyborcza/1,105406,11519173,_Nietykalni__Stara_Francja_ i_Arlekin.html [dostęp: 30.04.2017].

7 Tekst polski: Anna Gronowska. 
odegrania przez aktorów odpowiednich emocji za pomocą mimiki i gestów. Tu właśnie zaczyna się wyzwanie, przed którym staje audiodeskryptor: poprzez odpowiedni opis ma on odsłonić humor wypowiedzi w kontekście danej sytuacji. Jest to swojego rodzaju wyścig z czasem. Niekiedy, przy mniejszym natężeniu dialogów, z powodzeniem można zmieścić w opisie i informacje dotyczące akcji, i opis mowy ciała wraz z objaśnieniem jej znaczenia, na przykład: „Marcel podaje Drissowi gumową rękawiczkę. Driss patrzy z niechęcią, bierze. Marcel puszcza do niego oko", podczas gdy innym razem (gdy gesty i znacząca mimika pojawiają się tuż po słowach lub razem z nimi, a sceny zmieniają się szybko jedna po drugiej) nawet o wiele uboższy opis jest niemożliwy do wprowadzenia.

Humor tekstu wyjściowego (obrazu filmowego) jest oddany lub - miejscami - kompensowany przez język AD bogaty w zwroty kolokwialne. Można powiedzieć, że język ten przejawia elementy ludyczności, przez co pasuje do gatunku filmowego, jakim jest komedia. Naprzemienne użycie różnych rejestrów - literackiego i potocznego - świetnie komponuje się z fabułą, w której młody chłopak z ulicy, zupełnie pozbawiony jakichkolwiek zasad dobrego wychowania, taktu czy hamulców społecznych, trafia do domu ludzi z wyższych sfer, gdzie obowiązują nienaganna etykieta i rozliczne zasady poprawnego współżycia między domownikami. Tak samo więc jak nieokrzesany Driss wprowadza nieco luzu do domu Philippa, potoczne określenia czy zabawne porównania, których odbiorca niekoniecznie by oczekiwał w AD, stają się ciekawym zabiegiem stylistycznym i bawią. I tak „szeroko uśmiechnięty Driss” kilkukrotnie „błyska białymi zębami”, czasem „szczerzy” je, ,zaśmiewa się” lub tylko „uśmiecha się pod nosem”, a jego jego dokonania artystyczne w AD nazwane są „,bryzgami czerwonej farby”. W innym fragmencie dowiadujemy się, że „Yvonne z kwaśną miną ciska ciastkiem na stół”, gdy po uwadze Drissa na temat jej kłopotów z trawieniem, jakby przyłapana na gorącym uczynku, rezygnuje z dalszej konsumpcji ciasteczka i rzuca je na blat stolika, krzywiąc się przy tym z niesmakiem i niezadowoleniem. Z kolei moment, kiedy rozłożony na wielkim łóżku Driss zauważa portret nobliwego przodka karcącym wzrokiem spoglądającego na niego ze ściany, opisany jest tak:

Driss jednym susem wskakuje na łóżko. Szeroko rozkłada ramiona i nogi, unosi głowę. Zauważa portret mężczyzny w długiej peruce i zbroi. Sportretowany patrzy surowo.

Driss: Co? 
I więcej przykładów:

Driss pokazuje kolorową ulotkę. Atrakcyjna dziewczyna pręży biust. Philippe: Do kosza.

Driss: Jest niezła. Może założyć teczkę z dziwkami?

Driss szczerzy zęby, Philippe patrzy beznamiętnie. Ulotka ląduje w koszu.

Driss ubiera Philippa. Chwyta go wpól, podryguje jak w tańcu. Filip roześmiany.

Driss śmiało ujmuje Filipa wpól. Jak wielką lalkę przenosi go na wózek.

Driss bombarduje Philippa śnieżkami.

Film ten ma jednak nie tylko bawić widza, ma mu także pozwolić odczuć inne emocje oraz przekazać emocje przeżywane przez bohaterów, uwyplukając w ten sposób elementy komiczne. Dzieło filmowe jest sztuką mimetyczną i może nas poruszać właśnie dlatego, że odzwierciedla to, co znamy z prawdziwego życia i/lub co możemy odnieść do własnego doświadczenia. Im więcej znajdujemy w filmie znajomych emocji ${ }^{8} \mathrm{i}$ im wiarygodniej są one zagrane, tym silniejsze jest oddziaływanie obrazu na widza. Poza emocjami, które możemy wyczytać $\mathrm{z}$ tonu głosu aktorów przebijającego się spod kwestii lektora, to właśnie niewerbalne środki komunikacji oraz sposób konstrukcji sceny są źródłem informacji, które pozwalają nam uwierzyć w to, co widzimy. W AD do Nietykalnych dominują dwie tendencje w opisie emocji bohaterów i wyrażających je gestów: najczęściej język ciała jest opisany, a jego znaczenie dodatkowo objaśnione (np. ,gestykuluje wzburzony”, „otwiera usta ze zdumienia”, „Driss z troską popatruje na Philippa”, „urzędniczka zalotnie muska dłonią swój policzek”), równie często nastroje są nazwane wprost (np. „Philippe ubawiony”, „obaj poważni”, „Philippe wzruszony”). Znacznie mniej znajdujemy miejsc, gdzie opisany jest język ciała, a jego znaczenie jest łatwe do zinterpretowania poprzez kontekst (np.: „energicznie rusza głową w rytm muzyki”, „Driss spuszcza głowę”, „matka przy stole płacze, wspiera twarz na dłoni”), są też miejsca, w których

${ }^{8}$ Choćby w kontekście zupełnie nieprzystającym do znanej nam rzeczywistości. Zresztą Arystoteles w swojej Poetyce wspomina, że pewien dystans pomiędzy przedstawianymi zdarzeniami a życiem jest konieczny do tego, by widz mógł przeżyć katharsis. O tym, jak wielkie znaczenie ma odpowiednie odwzorowanie emocji w dziele filmowym, piszą również, odwołując się do innych autorów, Vercauteren i Orero (2013). 
zarówno opis gestów czy mimiki, jak i zdefiniowanie ich znaczenia autorzy AD zdecydowali się zupełnie opuścić.

Nastrój w AD budowany jest także poprzez opisy miejsc odwołujące się do zakorzenionych w naszej wyobraźni skojarzeń. W ten sposób na przykład o domu zamożnego Philippa dowiadujemy się, że prowadzi do niego „brama z jasnego drewna, wysoka, bogato zdobiona”, wnętrze natomiast jest „stylowe”, ze „złoconą boazerią (...) zabytkowymi meblami, bibelotami”; w jednym z opisywanych pomieszczeń „na ścianach wiszą wielkie obrazy w złoconych ramach, na środku fortepian”. „Służbówka” przydzielona Drissowi określona jest z kolei jako „czerwony apartament”, co stanowi spory kontrast z okolicą, z jakiej pochodzi chłopak - blokowiskiem opisywanym głównie jako skupisko „wysokich” bądź też „wielkich szarych bloków mieszkalnych”, gdzie jego liczna rodzina zajmuje „ciasne mieszkanie".

Pod koniec filmu, gdy Driss wraca do tęskniącego za nim Philippa, dwaj przyjaciele jadą nad morze drogą ciągnącą się pośród malowniczych krajobrazów. Scenie towarzyszy nastrojowa muzyka, na jej tle - równie nastrojowy opis wprowadzony w AD:

Wzdłuż szosy ciągnie się rozlewisko. Zielono-brązowe łaty ziemi na tle błękitnej tafli wody. Po drugiej stronie szosy rozległa łąka. Na horyzoncie pas morza nieco ciemniejszy od błękitu bezchmurnego nieba.

Skrypt AD do Nietykalnych czytany jest przez lektora, mężczyznę o bardzo przyjemnym głosie, który brzmi neutralnie, choć niebeznamiętnie. Lektor raz po raz zmienia tempo czytania, czasem w jego głosie pobrzmiewa nuta nostalgii, smutku czy współczucia, czasem ironii, radości lub rozbawienia, dzięki czemu wiele emocji obecnych w warstwie wizualnej udaje się ocalić również dla odbiorcy niemającego do niej dostępu.

Pozostaje wspomnieć jeszcze o emocjach utraconych w tej AD. Nie jest moim celem analiza wyborów dokonanych przez jej autorów ani dociekanie, co można było zrobić lepiej czy chociażby inaczej. Niezależnie od rodzaju tekstu, każde jego tłumaczenie będzie nieco inne, równie dobre lub - jeśli ktoś woli-równie niedoskonałe w stosunku do oryginału. Ponieważ jednak, o czym wspominałam już kilkakrotnie w tym artykule, emocje w Nietykalnych są widzom przekazywane dyskretnie poprzez mowę ciała istniejącą w kontekście (np. w kontekście dialogu lub jakiejś akcji), a szybkość scen nie pozwala opisać w AD wszystkiego, część humoru oraz innych emocji 
nieuchronnie dociera do niewidomego odbiorcy w znacznym uproszczeniu lub zostaje całkowicie utracona. Oto kilka przykładów.

W gabinecie siedzą Philippe i jedna z jego pracownic, Yvonne. Nagle do pomieszczenia wpada wzburzony Driss i w bardzo bezpośredni sposób, żwawo gestykulując, wyrzuca Philippowi, że ten ignoruje zachowanie córki, która nie okazuje szacunku domownikom - na przykład do pokoju Drissa wchodzi bez pukania, przeszkadza mu w malowaniu i na dodatek zwraca się do niego w bardzo niegrzeczny sposób. Kiedy chłopak wychodzi, Philippe z rozbawioną i zdziwioną miną, lekko ironicznie pyta Yvonne: „To on coś maluje?", na co reakcją jest zabawny grymas na twarzy kobiety połączony z uniesieniem ramion, mającym pokazać, że kobieta nie wie i że sama pierwsze słyszy. W całej tej scenie podstawą jest komunikacja za pomocą mimiki i gestów, zawartych w nich bezgłośnych pytań i odpowiedzi. Brak adekwatnych opisów, niemożliwych do wprowadzenia przez potok słów z ust Drissa, mocno ją zubaża i odbiera jej sporo z oryginalnego komizmu.

Bardzo podobnie rzecz ma się na początku filmu, gdy przedstawiana jest trudna sytuacja rodzinna Drissa. Z oglądanych scen dowiadujemy się, jak bardzo pogrążeni są jego bliscy w swojego rodzaju poczuciu beznadziei czy marazmie, $\mathrm{z}$ których nie są w stanie się uwolnić. I tu opisy emocji są bardzo uproszczone w stosunku do tego, co możemy zobaczyć na ekranie, na przykład gdy Driss obserwuje, jak pod blokiem jego młodszy brat wysiada z drogiego samochodu i robi gest, jak gdyby ocierał łzy (nie wspomina się o tym w AD, ale można się domyślać, że ma jakieś kłopoty).

\section{Adama wchodzi do mieszkania.}

Driss: Gdzie byłeś?

Adama: W szkole.

Adama, nie ogladając się, wchodzi do pokoju, wychodzi.

Driss: Dokąd idziesz?

Adama: Na konie.

Driss: Nie zgrywaj się.

Driss zasępiony.

Scena ta jest dość łatwa do zrozumienia nawet bez AD, ponieważ bazuje przede wszystkim na dialogach. Niemniej jednak, właśnie ze względu na brak opisu mimiki bohaterów, znaczących spojrzeń wymienianych przez braci, niewidomemu odbiorcy musi umknąć niemalże cała złożoność sytuacji, a zwłaszcza przedstawionych w niej emocji. Wspomniane spojrzenia w przypadku Drissa mówią, że chłopak zdaje sobie sprawę z tego, 
jak wielkich kłopotów mogą Adamie przysporzyć znajomości, w które się wplątał, wyraźnie przejmuje się tym i - choć sam ma podobne doświadczenia - zdecydowanie nie pochwala tego, że Adama bierze zlecenia od dealerów. Adama z kolei zdaje się mówić wzrokiem: „,co głupio pytasz, gdzie idę, dobrze wiesz, nie mam wyboru, takie mamy życie, taka jest nasza rzeczywistość".

Brak możliwości opisania w AD detali związanych z mową ciała skutkuje także stosunkowo uboższym obrazem charakterów postaci ${ }^{9}$. Brakuje na przykład opisu ruchów Drissa - płynnych, nonszalanckich, może nieco luzackich, ale zdradzających, że chłopak potrafi być porywczy. Gdy coś mówi, zwłaszcza podekscytowany lub zdenerwowany, gestykuluje gwałtownie i zamaszyście, jakby rapował. Dodatkowo na jego twarzy doskonale widać wszystkie targające nim emocje. To po pierwsze zdradza jego charakter i temperament, po drugie stanowi jasny kontrast z raczej powściągliwą, stonowaną, a momentami wręcz oschłą mimiką Philippa. I jest to tym bardziej istotne, że cała niezwykłość przyjaźni pomiędzy tymi dwoma mężczyznami kryje się właśnie w ich skrajnej odmienności. Aby pokazać stopniowo rodzącą się między nimi więź, reżyser posługuje się serią krótkich obrazów kilkusekundowych ujęć, na których Driss i Philippe wspólnie spędzają razem czas, nie tylko na rozmowach, ale też, a może przede wszystkim, na innych czynnościach, na przykład uprawiają razem ,jogging” (w tym celu wózek Philippa zostaje poddany tuningowi), palą skręty, odwiedzają salony masażu erotycznego, wygłupiają się. Driss często zapomina o niepełnosprawności Philippa lub z niej żartuje, a w czasie codziennej opieki nad mężczyzną bawi się nim jak lalką lub naigrywa z niego, niemniej jednak robi to w sposób pełny serdeczności i niekłamanej sympatii. W ten sposób przywraca Philippowi radość z życia, sam dostając w zamian szansę na lepsze i przede wszystkim uczciwe życie. Za tymi szybkimi obrazami stoi więc ogromny ładunek emocjonalny, który najpewniej z powodów technicznych do pewnego stopnia musiał zostać w tej AD utracony.

9 Te niekiedy wprowadza się poprzez załączenie w osobnych zakładkach w menu dvd/ blu-ray opisów postaci, z którymi widzowie mogą się zapoznać przed obejrzeniem filmu. Wcześniej dostarczone opisy postaci czy dekoracji znajdują zastosowanie również w przypadku sztuk teatralnych. Niemniej jednak takie opisy, jakkolwiek pozwalają na lepsze ,,poznanie" bohaterów, nie zastąpią opisów mowy ciała oraz wrażeń i emocji z nimi związanych w poszczególnych scenach. 


\section{Audiodeskrypcja artystyczna w przykładach}

Niniejsze rozważania na temat możliwości oddania nastroju obrazów filmowych poprzez odpowiednią kompozycję i język AD oraz kompensacji przez nie strat niemożliwych do wyeliminowania w produkcie finalnym chciałabym zilustrować za pomocą jeszcze kilku dodatkowych przykładów zaczerpniętych z AD do innych filmów, z których - jak sądzę - każda może być uznana za AD artystyczną. Pierwszą z nich napisano do filmu Pora umierać (2007). Ten czarno-biały obraz w reżyserii Doroty Kędzierzawskiej to melancholijny monolog jednej postaci - kobiety o imieniu Aniela, która przeżywa samotnie starość, obserwując świat zewnętrzny, a jedyna troska, jaką kobieta zdaje się mieć, to troska o los domu, w którym mieszka.

Pora umierać to utrzymana w nostalgicznej, poetyckiej tonacji (...) opowieść o starości, przemijaniu i samotności, o pragnieniu bycia potrzebnym aż do końca, o wierności zasadom i wartościom, które nie powinny ustępować przed naporem nowego tylko dlatego, że to nowe jest silniejsze, bardziej przebojowe, zachłanne. W filmie niewiele się dzieje, ale od wydarzeń i wartkich dialogów ważniejsze są tu nastroje, spojrzenia, gesty ${ }^{10}$.

Nostalgiczny nastrój świetnie oddaje $\mathrm{AD}^{11}$ - bogata w tekst i drobiazgowe, sugestywne opisy, a jednak pozwalająca wybrzmieć ciszy, spokojna, stonowana, odczytana miarowym, łagodnym męskim głosem, niewybijająca się ponad film, tak jak obraz filmowy nie wykracza poza określoną gamę barw. Nie jest to jednak głos płaski, wręcz przeciwnie, można odnieść wrażenie, że emocje bohaterki stały się udziałem lektora czytającego skrypt. Wszystkie te emocje, wyrażone na przykład uniesieniem brwi czy wzruszeniem ramion, wybrzmiewają wyraźnie, choć subtelnie, dzięki intonacji lektora. Podobnie zresztą jak ruch dłoni, jakim kobieta podnosi filiżankę do ust. Dynamika ruchów czy gestów bohaterów znajduje odzwierciedlenie w przyspieszonym lub spowolnionym tempie czytania skryptu AD, zawieszaniu głosu czy przesunięciach akcentów w poszczególnych zdaniach. Gdy Aniela ucieka we wspomnienia, a na ekranie w zwolnionym tempie pojawiają się rozmyte obrazy sprzed lat i rozlega się towarzysząca im delikatna muzyka, można

\footnotetext{
${ }^{10} \mathrm{http}: / / w w w . f i l m p o l s k i . p l / f p / i n d e x . p h p ? f i l m=1217746$ [dostęp: 30.04 .2017$]$.

11 Tekst AD: Anna Jankowska, Ewa Kurdas i Przemysław Zdrok.
} 
odnieść wrażenie, że lektor odczytuje opis na jednym oddechu, jakby „przelewał” słowa, te natomiast „rozpływają się” w muzyce.

Atmosferę oryginału bardzo wiernie oddaje też AD napisana do wyreżyserowanego przez Andrzeja Wajdę filmu Pan Tadeusz (1999), który za sprawą pięknie skomponowanych, malowniczych scen przesycony jest romantycznym poetyzmem i magią. Innowacyjność i artyzm tej AD są efektem wtopienia w jej tekst fragmentów dzieła Mickiewicza ${ }^{12}$, na przykład:

W kamienicy Adam Mickiewicz zamyka okno saloniku, wpatrzony w plik trzymanych w dłoni kartek. Wchodzi Protazy z naręczem drew. Mickiewicz zwraca się ku reszcie towarzystwa. Pogodny dzień. Wąską drogą wijącą się między wzgórzami jedzie dwukonna bryka. Wzgórza okrywa zielony dywan traw, przetykany barwami drobnych kwiatków. Napis na tle obrazu: Adam Mickiewicz: Pan Tadeusz. Bryka mija drewnianą kapliczkę na słupie. Powozi Tadeusz, młody smukły blondyn w ciemnoszarej czamarze ściągniętej pasem. Z uwagą rozgląda się po okolicy. Jedzie dalej... Do tych pagórków leśnych, do tych tąk zielonych, Szeroko nad btękitnym Niemnem rozciagnionych; Do tych pól malowanych zbożem rozmaitem, Wyzłacanych pszenica, posrebrzanych żytem.

Promyki słoneczne odbiły się na tożu o chorego głowę i ubrały mu złotem oblicze i skronie.

W ogrodzie przed dworem... Długie stoły, przy nich włościanie. Idą wzdłuż stołu... Po strunach cymbałów... śmigają pałeczki. Wychodzą z dworu. Jankiel kręci głową... Zosia z powagą zagląda w oczy Jankiela. On głaszcze jej policzek. Bierze cymbały, kładzie na kolanach, siada przed dworem. Zosia uśmiecha się, zadowolona z siebie. Poloneza czas zacząć. Goście wstają od stołów. Rusza korowód. W parkowej alejce pary idą jedna za drugą. Damy i panowie dostojnie krążą wokół siebie. Kłaniają się wytwornie. Pary zmieniają szyk. Suną ławą. W drugiej parze Dąbrowski i Podkomorzyna, dalej Sędzia i Podkomorzan$\mathrm{ka}$, Telimena $\mathrm{z}$ Rejentem... Zosia $w$ zielonej sukience, Ustrojona $w$ równianki $i$ w kwieciste wieńce, Śód traw i kwiatów krąży niewidzialnym lotem, Rządząc tańcem, jak aniot nocnych gwiazd obrotem. Zgadniesz gdzie jest: bo ku niej obrócone oczy, Wyciagnięte ramiona, ku niej zgietk się tłoczy. Aż Zosia, już strudzona, spotkała z kolei Tadeusza... I szły pary po parach hucznie $i$ wesoło, Rozkręcato się, znowu skręcato się koto, Jak wą̇ olbrzymi w tysiąc tamiacy się zwojów; Mieni się cętkowata, różna barwa strojów Damskich, pańskich, żotnierskich, jak tuska błyszczaca, Wyzłocona promieńmi zachodniego słońca I odbita o ciemne murawy wezglowia. Wre taniec, brzmi muzyka, oklaski i zdrowia!

${ }^{12}$ Cytaty z Mickiewicza zapisane kursywą. Ten sam zabieg stosuje Dorota Dziadkiewicz w AD do filmu Potop. 
Dodatkowo autorzy tej AD stosują bardzo liczne przenośnie i metafory, nie stronią też przed nazywaniem emocji wprost. W związku z tym znajdujemy tutaj takie opisy jak:

Przemarsz wojsk obserwują bociany. Jeden z ptaków wzbija się w powietrze. Kołuje nad doliną. Na rozstajnych drogach na oddziały piechoty czekają konni kirasjerzy w srebrzystych puklerzach. Strumienie ludzi lączą się w rzeki, rzeki płyną obok siebie nieprzerwanie. Mieszają się. Grenadierzy, woltyżerzy, kirasjerzy... Mundury niebieskie, czarne, białe, czapki wysokie i niskie, różnokolorowe ozdoby.

Wszyscy pogrążeni w smutnej zadumie.

Prusak ciska gniewne spojrzenie.

Kolejnym bardzo ciekawym zabiegiem jest stworzenie AD pierwszoosobowej. Na stronie internetowej projektu ADAPTER ${ }^{13}$ możemy obejrzeć Potop (na kanwach powieści Sienkiewicza) uzupełniony o AD opisującą zdarzenia z perspektywy jednej z postaci, w tym wypadku Andrzeja Kmicica $^{14}$. Chciałabym przytoczyć dwa fragmenty - początek i koniec tej AD:

Jam jest Andrzej Kmicic, pułkownik wojsk litewskich Pierwszej Rzeczypospolitej. Oto staję przed wami i pragnę opowiedzieć wam historię mojego upadku i mojego odkupienia. I historię miłości, która pozwoliła mi przetrwać. Historię, którą wielu z was mogło już słyszeć, ale która dotychczas pełna była fałszu. Choć niektóre wypadki znam jedynie z opowieści, trwają w mej wyobraźni tak żywo, jakbym był ich świadkiem. Gdy tylko przymknę powieki, wydarzenia sprzed lat jawią się przede mną niby ruchome obrazy. Oto znów jest mroźny styczeń roku 1655. Znów śnieg pokrywa Żmudź. Rozległe pole mozolnie przemierza grupa wycieńczonych żołnierzy. Mają na sobie zniszczone, porozdzierane łachmany. Wielu nosi przekrwione opatrunki na głowach i kończynach...

Tulę do siebie roześmianą Oleńkę i przepełnia mnie radość, jakiej nie jestem w stanie wyrazić. Razem ze wszystkimi gośćmi zajeżdżamy do dworu w Wodoktach i oto jesteśmy teraz tutaj, na naszej zaręczynowej uczcie. Znacie już, drodzy współbiesiadnicy, wszystkie wypadki, które doprowadziły mnie do tego miejsca i do Oleńki. Wznieśmy więc teraz kielichy i wypijmy toast za miłość i za pokój ojczyzny. Oby mogły trwać wiecznie.

13 Projekt Fundacji Katarynka, w zakładce ADAPTER w szkole możemy znaleźć m.in. adaptacje filmowe lektur szkolnych z audiodeskrypcją i/lub napisami dla niesłyszących.

14 Tekst AD: Przemysław Zdrok. 
Kmicic snuje swoją opowieść, nie unikając przy tym interpretowania opisywanych wydarzeń. O swoich losach opowiada z pasją w głosie, z namiętnością godną butnego szlachcica i zabijaki, jakim w rzeczywistości był. Jego gorliwość jest zaraźliwa, sprawia, że widz zostaje dosłownie wchłonięty przez to niemalże baśniowe słuchowisko. Tak skonstruowana AD ma więc bardzo praktyczne przełożenie na budowanie atmosfery i pozwala na nowo zachwycić się opowieścią Sienkiewicza.

Za pomocą $\mathrm{AD}$ pierwszoosobowej można też z łatwością stopniować emocje, czego bardzo dobrym przykładem zdaje się $\mathrm{AD}^{15}$ do filmów Bibi Blocksberg - mała czarodziejka (2002) oraz Bibi Blocksberg i tajemnica niebieskiej sowy (2004). Została ona napisana z punktu widzenia ojca tytułowej bohaterki i - podobnie jak obraz - miejscami ma śmieszyć widza, na przykład:

Kula stacza się z łóżka i ląduje gdzie? Oczywiście na moim palcu! Podrywam się i skaczę na jednej nodze tam i z powrotem.

Może też trzymać go w napięciu:

Rabia wchodzi do pokoju, w którym śpi Bibi. Taca jest przykryta ściereczką. Rabia zbliża się do łóżka Bibi, odkłada tackę. Pochyla się nad Bibi. Co ona robi? Bibi, obudź się!

Dalej w filmie mamy dialog: - Rabia rozmawia z nieświadomą niebezpieczeństwa Bibi. Po nim zaś następuje ciąg dalszy AD; ojciec dziewczynki przez wykrzyknienie, którym chce przestrzec ją przed wypiciem magicznej mikstury, wyraża grozę sytuacji:

Wręcza Bibi filiżankę napoju zaufania. Nie pij tego!

W przywoływanej AD nie brakuje też miejsc, gdzie wprost i subiektywnie nazywa się targające postaciami emocje, na przykład:

Jestem bardzo poruszony i chyba zaraz zacznę płakać.

15 Oryginalny tekst AD: Monika Buhtz, Petra Kirchmann i Sabine Ziehm, redakcja i adaptacja na potrzeby dzieci: Bernd Benecke i Elmar Dosch. Tłumaczenie na język polski (na potrzeby niniejszego artykułu): Monika Zabrocka. 
Jako ostatni przykład posłuży mi rymowana AD do krótkometrażowego animowanego filmu Odbijany (2003), którą przygotowałam na potrzeby badań nad odbiorem AD w zależności od jej języka i formy ${ }^{16}$. O wyborze takiej formy AD zadecydował charakter samej animacji, w której narracja oraz dialogi również opierają się na rymach. W proponowanej przeze mnie AD rymy pojawiają się w obrębie poszczególnych zdań, niekiedy też opisy wprowadzane przez AD rymują się z kwestiami wypowiadanymi przez bohaterów. Poniżej przedstawiam kilka przykładów:

Owca - świadoma swojej urody - przegląda się w tafli wody.

Nagle nadjeżdża furmanka, zaczyna się owiec łapanka.

AD: Hulajlama spojrzenie śle im ostre, jak nóż.

Dialog, Hulajlama: Róż? Róż? A złego w tym cóż?

Wielki królik z rogami jagniątko za nóżkę chwyta i uczy je, jak w górę wyrzucać kopyta.

Jagnię, szczęśliwe jak trzeba, skacze wysoko do nieba.

Przy każdym zaś jego podskoku zmieniają się pory roku.

Jagnię tymczasem w wełnę obrasta i czeka, spokojnie - rzecz jasna,

aż znowu przyjedzie furmanka i zacznie się owiec łapanka.

Jedną z najistotniejszych kwestii dotyczących AD rymowanej było jej bardzo pozytywne przyjęcie przez dzieci i dorosłych (w obu grupach respondentów były zarówno osoby z dysfunkcją wzroku, jak i widzące). Choć AD rymowanej konsekwentnie zarzucano brak obiektywności (dorośli), to jednak uznano ją za bardzo atrakcyjną. Widzowie dostrzegli też jej potencjał: uznali, że dzięki niej film wydawał się zabawniejszy, a tak skomponowana AD sama w sobie stanowiła rozrywkę, co zdaniem respondentów czyni z niej narzędzie idealne na przykład do opisu niemych filmów animowanych.

16 Dokładny opis wyników dotyczących AD rymowanej znajduje się w dwóch artykułach mojego autorstwa: Zabrocka 2014a i 2014b. W druku jest trzeci artykuł - anglojęzyczny, łączący oba poprzednie i uzupełniający je o późniejsze badania (również wymieniony w bibliografii jako Zabrocka 2018). 


\section{Podsumowanie: audiodeskrypcja jako dzieło sztuki}

Celem analizy przedstawionej w tym artykule było zbadanie, ile $\mathrm{z}$ oryginalnego charakteru dzieła - zwłaszcza zaś emocji i komizmu zawartego w poszczególnych scenach - udało się zachować autorom AD do filmu Nietykalni, a co zostało utracone i dlaczego. Ponadto chciałam zwrócić uwagę na możliwości oddziaływania za pomocą AD na nastrój odbiorcy, a moje rozważania zilustrować przykładami zaczerpniętymi z tego kinowego hitu, który jest przesycony humorem i emocjami. Stąd też starałam się wskazać te miejsca, gdzie subtelności emocji i komizmu nie mogły zostać oddane w pełni ze względu na ograniczenia czasowe, jakim podlega AD. Dodatkowo, przedstawione w tekście studium przypadku stanowiło dla mnie punkt wyjścia do podjęcia niezwykle istotnego w moim odczuciu tematu AD artystycznej. Poprzez przykłady pochodzące zarówno z Nietykalnych, jak i z innych filmów chciałam podkreślić, jak duży potencjał na omawianym polu ma właśnie $\mathrm{AD}$ artystyczna i jak wspaniale można ją wykorzystać do wywołania u niewidomych odbiorców odpowiednich emocji, nastrojów i wrażeń estetycznych.

Dyskusyjna natomiast pozostaje niezmiennie kwestia neutralności czy obiektywności AD. Wydaje się, że ankietowani odbiorcy AD przywiązują szczególną wagę do tej cechy, a to jej najczęściej będzie brakować w AD artystycznej (por. Szarkowska, Wasylczyk 2014). Martínez-Sierra (2010), w ramach polemiki z postulatem neutralności języka $A D$, zadaje niezwykle istotne pytanie o to, czy humor, a w związku z tym i AD, która ma go oddać, mogą być neutralne. Aby przedstawione emocje nie zostały utracone w tłumaczeniu, niezbędne wydaje się elastyczne podejście do kryterium obiektywności i interpretowanie obrazu filmowego na tyle, by powstałe tłumaczenie - AD - dostarczało tych samych przeżyć natury estetycznej co orygina ${ }^{17}$, bo to właśnie poruszenia i emocji oczekuje się od kontaktu ze sztuką (Künstler 2014).

AD artystycznej zostało do tej pory poświęconych zbyt mało badań, by móc z całą pewnością stwierdzić, że podoba się ona potencjalnym odbiorcom bardziej niż AD tradycyjna. Niemniej istniejące analizy (m.in. Bencke, Orero, Szarkowska i Wasylczyk, Zabrocka, Fels et al. - wspominane we wprowadzeniu, por. także Vercauteren i Orero 2013) pozwalają

${ }^{17}$ W kontekście poezji pisze o tym np. Barańczak (2004). 
przypuszczać, że tworzenie AD artystycznej jest strategią tłumaczeniową właściwą w przypadku (większości) dzieł sztuki, mającą szansę kompensować niewidomym odbiorcom brak bodźców wizualnych w sposób pełniejszy, niż ma to miejsce w przypadku tradycyjnej AD. Jak pisze Robert Więckowski (2014), piękno jest wpisane w istotę dzieła sztuki i dlatego wrażenia zmysłowe wywołane napięciem estetycznym związanym z doborem środków wyrazu przez autora powinny zostać przekazane w odpowiednim opisie $\mathrm{AD}$, zaś opis, który nie stwarza warunków do przeżycia tego piękna, można uznać za niekompletny lub nawet zupełnie nieprzystający do oryginału i niepoprawny.

\section{Bibliografia}

Agryle M. 1988. Bodily Communication, Londyn-Nowy Jork: Methue \& Co. Ltd.

Barańczak S. 2004. Ocalone w tlumaczeniu, Kraków: Wydawnictwo A5.

Benecke B. 2015. Can You Believe It? - An Experiment with Subjective AD for Children, wystąpienie w czasie konferencji Audio Description and Education Symposium, Warszawa, 23-24 września 2015.

Branje C.J., Fels D.I. 2012. LiveDescribe: Can Amateur Describers Create High-Quality Audio Description?, „Journal of Visual Impairment \& Blindness” 106 (3), s. 154-165.

Braun S. 2007. Audio Description from a Discourse Perspective: A Socially Relevant Framework for Research and Training, „Linguistica Antverpiensia” 6, s. 357-369. Chmiel A., Mazur I. 2011. Audiodeskrypcja jako intersemiotyczny przeklad audiowizualny-percepcja produktu i ocena jakości, w: I. Kasperska, A. Żuchelkowska (red.), Przektad jako produkt i kontekst jego odbioru, Poznań: Wydawnictwo Rys, s. 13-30.

Deacon T. 1997. The Symbolic Species: The Co-Evolution of Language and the Brain, Nowy Jork: Norton.

Del Corral I. 1988. Humor: When Do We Lose It?, „Translation Review” 27, s. 25-27. Diot R. 1989. Humor for Intellectuals: Can It Be Exported and Translated? The Case of Gary Rudeau's in Search of Reagan's Brain, „Meta” 34 (1), s. 84-87.

Eco U. 2006. Dire presque la même chose. Experiences de traduction, Paryż: Édition Grasset et Fasquelle.

Jakobson R. 1960. Closing Statement: Linguistics and Poetics, w: T.A. Sebeok (red.), Style in Language, Cambridge: The MIT Press, s. 350-377.

Fels D.I., Udo P.J., Diamond J.E., Diamond J. 2006. A Comparison of Alternative Narrative Approaches to Video Description for Animated Comedy, „Journal of Visual Impairement \& Blindness" 100 (5), s. 295-305.

Jankowska A., Zabrocka M. 2016. How Co-speech Gestures Are Rendered in Audio Description: A Case Study, w: Researching Audio Description: New Approaches, Londyn: Palgrave Macmillan, s. 169-186. 
Künstler I. 2014. Cel uświęca środki audiodeskrypcji, „Przekładaniec” 28, s. 140-152. Laurian A-M. 1989. Humour et traduction, „Meta” 34 (1), s. 5-14.

Lipiński K. 2000. Vademecum tłumacza, Kraków: Wydawnictwo Idea.

Martínez-Sierra J.J. 2010. Approaching the Audio Description of Humour, „Entreculturas" 2, http://www.entreculturas.uma.es/n2pdf/articulo07.pdf. [dostęp: 12.05.2017].

Masson A. 2007. D'où vient le geste ?, w: V. Amiel, J. Nacache, G. Sellier, C. Vivian (red.), L'acteur de cinéma: approches plurielles, Rennes: Presses Universitaires de Rennes.

Orero P. 2011. Audio Description for Children: Once upon a Time There Was a Different Audio Description for Characters, w: E. Di Giovanni (red.), Entre texto y receptor: Accesibilidad, doblaje y traducción [Between Text and Audience: Accessibility, Dubbing and Translation], Frankfurt: Peter Lang, s. 169-184.

Poyatos F. 2002. Nonverbal Communication across Disciplines: Paralanguage, Kinesics, Silence, Personal and Enviromental Interaction, vol. 2, Amsterdam: John Benjamins Publishing Company.

Raphaelson-West D. S. 1989. On the Feasibility and Strategies of Translating Humor, „Meta” 34 (1), s. 128-141.

Rossini N. 2004. The Analysis of Gesture: Establishing a Set of Parameters, w: A. Camurri, G. Volpe (red.), Gesture-Based Communication I. Computer-Human Interaction. 5th International Gesture Workshop, GW 2003, Selected Revised Papers, Berlin-Heidelberg-New York: Springer, s. 124-131.

2012. Reinterpreting Gesture as Language, Amsterdam: IOS Press.

Sweetser E. 2006. Looking at Space to Study Mental Spaces: Co-speech Gesture as a Crucial Data Source in Cognitive Linguistics, w: M. Gonzalez-Marquez, I. Mittleberg, S. Coulson, M. Spivey (red.), Methods in Cognitive Linguistics, Amsterdam: John Benjamins, s. 201-224.

Szarkowska A. 2011. Text-to-Speech Audio Description: Towards Wider Availability of $A D$, „The Journal of Specialised Translation” 15, s. 142-162.

Szarkowska A., Wasylczyk P. 2014. Audiodeskrypcja autorska, „Przekładaniec” 28, s. $48-62$.

Udo P.J. Fels D.I., 2011. From the Describer's Mouth: Reflections on Creating Unconventional Audio Description for Live Theatre, w: A. Serban, A. Matamala, J.-M. Lavaur (red.), Audiovisual Translation in Close-up: Practical and Theoretical Approaches, Bern-Berlin: Peter Lang Verlag, s. 257-278.

Vandaele J. 1999. Each Time We Laugh: Translated Humor in Screen Comedy, „Translation and the (Re)Location of Meaning", s. 237-272.

2010. Humor in Translation, w: Y. Gambier, L. van Doorslaer (red.), Handbook of Translation Studies, vol. 1, Amsterdam-Philadelphia: John Benjamins Publishing Company, s. 147-152.

Vercauteren G., Orero P. 2013. Describing Facial Expressions: Much More than Meets the Eye, „Quaderns. Revista de traducció” 20, s. 187-199.

Waugh L.R. 1980. The Poetic Function in the Theory of Roman Jakobson, „Poetics Today" 2(1), s. 57-82.

Więckowski R. 2014. Audiodeskrypcja piękna, „Przekładaniec” 28, s. 109-123. 
Zabrocka M. 2014a. Audiodeskrypcja tradycyjna a audiodeskrypcja artystyczna: o wptywie języka i formy audiodeskrypcji na komfort jej odbioru przez osoby niewidome i niedowidzące, w: K. Jachimowska, B. Kudra, E. Szkudlarek-Śmiechowicz (red.), Stowo we współczesnych dyskursach, Łódź: Wydawnictwo Uniwersytetu Łódzkiego, s. $453-462$.

2014b. Audiodeskrypcja artystyczna w odbiorze osób niewidomych i niedowidzacych, w: M. Łukasik, B. Mikołajewska (red.), Języki specjalistyczne wczoraj, dziś i jutro, Warszawa: Wydawnictwo Naukowe Instytutu Kulturologii i Lingwistyki Antropocentrycznej Uniwersytetu Warszawskiego, s. 454-466.

2018. Rhymed and Traditional Audio Description According to the Blind and Partially Sighted Audience: Results of a Pilot Study on Creative Audio Description, „The Journal of Specialised Translation” 29, s. 212-236. 